\title{
COVID-19 pandemic: pain, quality of life and impact on public health in the confinement in Spain
}

\author{
Elvira Iglesias-López ${ }^{1}$, Sara García-Isidoro^ ${ }^{\wedge}, V^{\prime}$ ctor Omar Castellanos-Sánchez ${ }^{3} \wedge$ \\ ${ }^{1}$ AMPAF (Mirandás Association of People Affected by Fibromyalgia), Miranda de Ebro, Burgos, Spain; ${ }^{2}$ Department of Physical Therapy, Nursing \\ and Physical Therapy Faculty "Salus Infirmorum", Pontificial University of Salamanca, Madrid Campus, Madrid, Spain; ${ }^{3}$ Exclusivas DISAR SL, \\ Department of Research and Development, Madrid, Spain \\ Contributions: (I) Conception and design: E Iglesias-López, S García-Isidoro; (II) Administrative support: All authors; (III) Provision of study materials \\ or patients: E Iglesias-López, S García-Isidoro; (IV) Collection and assembly of data: E Iglesias-López; (V) Data analysis and interpretation: S García- \\ Isidoro; (VI) Manuscript writing: All authors; (VII) Final approval of manuscript: All authors. \\ Correspondence to: Sara García-Isidoro, PT, MsC, PhD; Sara García-Isidoro, PT, MsC, PhD. Facultad de Enfermería y Fisioterapia Salus Infirmorum, \\ Universidad Pontificia de Salamanca, Calle de Gaztambide, 12, 28015 Madrid, España. Email: sgarciais@upsa.es.
}

Background: Given the uncontrolled increase of those affected by the SARS-CoV-2 Coronavirus, COVID-19, and the possibility of the health system collapsing in Spain, the Royal Decree 463/2020, of March $14^{\text {th }}$, declared a state of alarm for the management of this health crisis. The whole population, despite their social background, were confined inside their homes during this arduous situation. There are numerous articles that endorse the idea that their home conditions, the number of people with whom they coexist with, their employment, gender, amount of physical exercise, as well as their body mass index and their diagnosis in COVID-19 are characteristics that may represent an increased risk of suffering pain and changes in their quality of life. We proposed a study to determine the impact of the confinement on pain, quality of life and public health of the Spanish population due to the COVID-19 pandemic.

Methods: An observational study was carried out during April and May 2020 through an online survey. It was statistically analysed through descriptive analysis and inferential analysis by bivariate logistic regression, ordinal logistic and Pearson's chi square.

Results: A total of 225 questionnaires were obtained between April and May 2020. For subjects suffering pain before confinement, significant relationships were drawn between experiencing pain and work-related activities $(\mathrm{P}=0.006)$, as well as, physical activity or the absence of it $(\mathrm{P}=0.033)$. In addition, an important association between experiencing pain and gender was discovered, both for people suffering pain before and during confinement $(\mathrm{P}=0.007$ and $\mathrm{P}=0.011)$. Furthermore, the confinement has affected the quality of life of those affected, particularly in relation with suffering pain before and during confinement $(\mathrm{P}=0.001$ and $\mathrm{P}=0.000)$, Job type $(\mathrm{P}=0.016)$ and $\mathrm{BMI}(\mathrm{P}=0.025)$ and affecting more Physical Role, Emotional Role and Mental Health, followed by Physical Function.

Conclusions: The presence of pain in subjects undergoing confinement is persistent, with varying intensity and frequency based on age, gender, physical activity, and work status. In any of these conditions, the quality of life of the subjects in confinement has been severely affected, which to this day creates a severe public health problem.

Keywords! COVID-19; social isolation; pain; quality of life

Submitted Dec 16, 2020. Accepted for publication Mar 15, 2021.

doi: 10.21037/apm-20-2514

View this article at: http://dx.doi.org/10.21037/apm-20-2514

\footnotetext{
^ ORCID of Elvira Iglesias-López: 0000-0003-3300-0624; Sara García-Isidoro: 0000-0003-4048-4903; Víctor Omar Castellanos-Sánchez: 0000-0002-5022-8092.
} 


\section{Introduction}

In Wuhan, China, an outbreak of respiratory infection caused by a new virus was detected in December 2019, called the SARS-CoV-2 Coronavirus (COVID-19), which quickly spread from the Asian continent to the rest of the world. The most common clinical characteristics of the patients with COVID-19 pneumonia were fever $(92.80 \%)$, cough $(69.80 \%)$, dyspnea $(34.50 \%)$, myalgia $(27.70 \%)$, pain head $(7.20 \%)$ and diarrhoea $(6.10 \%)$. To date, the virus is known to have an incubation time of 2 to 11 days, with potential asymptomatic transmission. Additionally, it was detected that the contagion is produced by Flugge drops, and that it was not only caused by subjects with active symptoms, but could also be transmitted by those who were asymptomatic (1). The prevalence of the virus in the population is unknown at this time, although studies are being carried out to ascertain this data (2).

Given this uncontrolled increase of those affected by the virus and the possibility of the health system collapsing in Spain, the Royal Decree 463/2020, of March $14^{\text {th }}$, declared a state of alarm for the management of the health crisis caused by COVID-19. A series of measures were imposed on the population that limited pedestrian movement and circulation on public roads, recommended teleworking, suspended schools and encouraged online teaching activities, suspended museum visits, restaurants, bars, cafes, sports centres. Face-to-face events of all kinds were cancelled and places of worship, civil and religious ceremonies were closed (3). This Royal Decree, with an initial duration of 15 days, was extended on several occasions, until the start of the phases of the so-called 'de-escalation' on May $4^{\text {th }}, 2020$ (4). In addition, the Spanish government attempted to alleviate this situation with the approval of the Royal Decree-Law 8/2020, on March $17^{\text {th }}$, related to the extraordinary urgent measures to be used to face the economic and social impact of COVID-19 (5).

The whole population, despite their social background, were confined inside their homes during this arduous situation. There are numerous articles that endorse the idea that their home conditions, the number of people with whom they coexist with, their employment, gender, amount of physical exercise, as well as their Body Mass Index (BMI) and their diagnosis in COVID-19 are characteristics that may represent an increased risk of suffering pain and changes in their quality of life (6-15).

This study has been proposed due to the abovementioned and the lack of knowledge of whether the measures adopted were the most appropriate in terms of avoiding contagion on a large scale and keeping the general population healthy. The main objective of the study is to determine the impact of the confinement to the Spanish population due to the COVID-19 pandemic in terms of pain, quality of life and health. In addition, the relationship between the obtained results and gender, the diagnosis of COVID-19, the company during home confinement, the job conditions, amount of exercise and the BMI is explored. We present the following article in accordance with the STROBE reporting checklist (available at http://dx.doi. org/10.21037/apm-20-2514).

\section{Methods}

An observational study was carried out on the impact of the measures adopted to stop the spread of COVID-19 in relation with the quality of life and pain experienced by the Spanish population. This data was obtained through the telematic distribution of an online survey on several social networks (Instagram, Facebook and Whatsapp). An extensive dissemination of the questionnaire was carried out through requesting its re-distribution in order to increase the range of survey participants in Spain. The ethical standards of the Research Committee and the Declaration of Helsinki of 1975 (revision of October 2013) were met. The study was submitted to the Committee for Research Ethics with drugs of the Health Area of Burgos and Soria, and due to the characteristics of the study, a waiver was provided.

The questionnaire was created from scratch in Google Forms. It consisted of 23 questions: 12 demographicsrelated and 11 associated with the SF-36 Health Questionnaire version 2 (SF-36v2). Prior to the questions, a brief explanation about the content of the questionnaire and its scientific purpose was provided. Data from the questionnaire was obtained from April $18^{\text {th }}$ to May $3^{\text {rd }}$, 2020 (the start date of the national 'de-escalation' plan in Spain). In Spain the entire population, both COVID-19 patients and healthy people, were forced to carry out home confinement in order to stop the disease spreading, as indicated by the RDL of the State of Alarm. At the beginning it was meant to be for 15 days, but finally it lasted up to almost two months. That is why the data collected is from confined people, because the entire population was confined. We could not collect data from unconfined people as a control group due to there was none in the same country.

Any incomplete questionnaires (with less than 20\% of 
answers) and those with inconsistent demographics have been excluded from the analysis.

Data related to age, gender, weight, height, company during home confinement, current work situation, physical exercise practice and diagnosis of COVID-19 were recorded. Additionally, information was sought on whether the subjects had suffered pain during confinement, or whether the pain had started prior to this situation, the subject's behaviour, and the amount of pain felt using a Numerical Pain Rating Scale (NPRS). The scale starts with 0 being no pain, up to 10 being the worst pain imaginable. The data obtained on the quality of life was collected through the SF-36v2 questionnaire, which considers eight different 'spheres' of quality of life: Limitation by physical function, Physical role, Body pain, General health, Vitality, Social function, Emotional role and Mental health, and Evolution of Health as separate items. The original translated questionnaire can be consulted, as it has been included in the article. The interested reader can find it in a supplementary appendix online (Appendix 1).

Due to the unprecedented situation lived in Spain and the rest of the world, and from which previous data is unknown, the calculation of the sample size was made with a pilot sample of the first participants of the questionnaire $(\mathrm{n}=30) .50 \%$ of them experienced pain during the confinement; therefore, a random sample of 385 individuals was deemed appropriate. Since the confinement situation changed on May $4^{\text {th }}, 2020$, it was deemed appropriate to conclude the data collection on this date.

The null hypothesis that had to be discarded was the following: Neither age, gender, weight, height, company during home confinement, current work situation, physical exercise practice and diagnosis of COVID-19 factors that could modify the possibility of suffering pain before or after confinement or change the perception of quality of life. A descriptive statistical analysis was performed using means and standard deviation for the quantitative variables, and using percentages for dichotomous and categorical variables. An inferential analysis was carried out using a bivariate logistic regression with the dichotomous variables and an ordinal logistic regression with the categorical variables to report odds ratios (OR), in order to carry out a predictive analysis. Pearson chi-square was also used to relate dichotomous and categorical variables in a transversal analysis. In all cases, a $\mathrm{P}<0.05$ value and a $95 \%$ confidence interval were used for the degree of statistical significance. All statistical analysis were performed using the Stata ${ }^{\circledR}$ version 14.2 package for MS Windows ${ }^{\circledR}$ version 10.

\section{Results}

A total of 225 completed questionnaires were obtained, of which $100 \%$ were fully answered. The sample was made up of mainly adult women (with mean age 43.4 years, $70.22 \%$ of the studied population), who were physically active (31.56\% exercised once a day) and with normal weight $(56.40 \%)$. The majority lived in a family home made up of more than two people $(62.05 \%)$ and were teleworking (24.00\%). Most did not present the symptoms of COVID-19 (79.11\%), but it is worth noting that, for the sample collected, there were as many subjects who had obtained a positive diagnosis by laboratory tests $(10.22 \%)$ as those subjects who had suffered from the symptoms of the disease but had not received a diagnosis (10.67\%). The characteristics of the sample can be seen in more detail in Table 1.

The variations in pain derived from the measures implemented to control the massive spread of COVID-19 in Spain, it can be seen that there are more subjects who report having pain during confinement $(46.22 \%)$ than previously (29.78\%). This pain suffered during confinement has an average intensity of 5.25 points on the NPRS scale; although most of the respondents who suffered pain acknowledged suffering it with high intensity: the most frequent pain scores were 6 points $(20.37 \%), 7$ points $(14.81 \%)$ and 8 points $(13.89 \%)$ (Table 2). It was found that suffering pain prior to confinement had no relationship with the company of the subject at home, nor with the received diagnosis nor COVID-19 symptoms (which could have been prior to the decree of alarm status) $(\mathrm{P}>0.05)$, but was related to gender (women suffer pain 2.56 times more than men) $(\mathrm{P}=0.007)$, exercise (mainly related to not exercising at all $\mathrm{OR}=1.58$ or, conversely, exercising daily, $\mathrm{OR}=1.67$; $\mathrm{P}=0.033$ ) and employment (suffering more pain by domestic workers, health personnel, people on sick leave and essential workers) $(\mathrm{P}=0.006)$. The relationship between $\mathrm{BMI}$ and pain was also observed, with obese people suffering more pain $(\mathrm{P}=0.028)$. It was found that neither company at home, nor employment, nor exercise were related to pain $(\mathrm{P}>0.05)$. However, confinement-related pain during the state of alarm was related to having suffered pain prior to the confinement $(\mathrm{OR}=34.25, \mathrm{P}=0.000)$, as well as, being a woman $(\mathrm{P}=0.011)$, having a positive COVID-19 diagnosis $(\mathrm{P}=0.000)$ and being overweight or obese $(\mathrm{P}=0.000)$ (Table 3). When comparing pain intensity with gender, it draws for attention that not only women are more likely to suffer pain, but also suffer a wider range of pain intensity, reaching for higher scores on NPRS (Figure 1). Regarding 
Table 1 Characteristics of the sample

\begin{tabular}{|c|c|}
\hline Characteristics & Values \\
\hline Age (years), mean \pm SD (range) & $43.38 \pm 15.73$ (15 to 74$)$ \\
\hline Weight $(\mathrm{kg})$, mean \pm SD (range) & $69.69 \pm 14.25$ (45 to 150$)$ \\
\hline Height $(\mathrm{m})$, mean \pm SD (range) & $1.68 \pm 0.10(1.49$ to 1.95$)$ \\
\hline BMI $\left(\mathrm{kg} / \mathrm{m}^{2}\right)$, mean $\pm \mathrm{SD}$ (range) & $24.67 \pm 4.01$ (17.58 to 39.45$)$ \\
\hline \multicolumn{2}{|l|}{ Gender, n (\%) } \\
\hline Male & $65(28.89)$ \\
\hline Female & $158(70.22)$ \\
\hline Rather not to say & $2(0.88)$ \\
\hline \multicolumn{2}{|l|}{ BMI, n (\%) } \\
\hline Underweight & $3(1.33)$ \\
\hline Normal weight & $127(56.44)$ \\
\hline Overweight & 77 (34.22) \\
\hline Obesity & $18(8.00)$ \\
\hline \multicolumn{2}{|l|}{ Home type, n (\%) } \\
\hline Lives alone & $15(6.70)$ \\
\hline $\begin{array}{l}\text { Lives alone with company } \\
\text { during the day }\end{array}$ & $6(2.68)$ \\
\hline Lives with another person & $64(28.57)$ \\
\hline $\begin{array}{l}\text { Living with more than two } \\
\text { people }\end{array}$ & $139(62.05)$ \\
\hline \multicolumn{2}{|l|}{ Job type, n (\%) } \\
\hline Unemployed & $13(5.78)$ \\
\hline Domestic work & $27(12.00)$ \\
\hline Student & $23(10.22)$ \\
\hline Public job/studies candidate & $4(1.78)$ \\
\hline Health professional & $15(6.67)$ \\
\hline Minimum service worker & $8(3.56)$ \\
\hline Food sector & $5(2.22)$ \\
\hline State security forces & $3(1.33)$ \\
\hline Teleworking & $54(24.00)$ \\
\hline ERTE & $32(14.22)$ \\
\hline Retired & $18(8.00)$ \\
\hline Medical sick leave & $7(3.11)$ \\
\hline Usual work practice & $12(5.33)$ \\
\hline Others & 4 (1.78) (autonomous worker) \\
\hline
\end{tabular}

Table 1 (continued)
Table 1 (continued)

\begin{tabular}{lc}
\hline Characteristics & Values \\
\hline Exercise, $\mathrm{n}(\%)$ & $15(6.67)$ \\
More than once a day & $71(31.56)$ \\
At least once a day & $30(13.33)$ \\
More than three times per week & $32(14.22)$ \\
Two or three times per week & $33(14.67)$ \\
One or two times per week & $8(3.56)$ \\
Twice a month & $34(15.11)$ \\
I do not practice exercise & \\
Others & $23(10.22)$ \\
COVID-19, $n$ (\%) & $178(79.11)$ \\
Yes & $24(10.67)$ \\
No & \\
Maybe (symptoms coincide), \\
but I have not been diagnosed
\end{tabular}

Table 2 Variations in pain derived from the measures implemented to control the massive spread of COVID-19 in Spain

\begin{tabular}{lc}
\hline Pain characteristics & Values \\
\hline Pain before confinement, $\mathrm{n}(\%)$ & $67(29.78)$ \\
Yes & $158(70.22)$ \\
No & \\
Pain during confinement, $\mathrm{n}(\%)$ & $104(46.22)$ \\
Yes & $121(53.78)$ \\
No & \\
Pain quality, $\mathrm{n}$ (\%) & $13(12.26)$ \\
Has pain but cannot describe it & $34(32.08)$ \\
Constant pain during confinement & $13(12.26)$ \\
Decreasing pain during confinement & $22(20.75)$ \\
Increasing pain during confinement & $24(22.64)$ \\
Brief pain (less than 7 days) & $5.26 \pm 2.27(0$ to 10$)$ \\
\hline NPRS, mean \pm SD (range)
\end{tabular}

the relationship between job type and intensity of pain, it is noticeable that, although there is no significative differences between Odds Ratios, domestic workers suffer a mean of pain of 6 at NPRS, but also are capable of suffering 
Table 3 Relationship between pain and life-style factors

\begin{tabular}{|c|c|c|c|c|c|c|c|c|}
\hline Life-style factors & \multicolumn{4}{|c|}{ Pain before confinement } & \multicolumn{4}{|c|}{ Pain during confinement } \\
\hline Pain before confinement & & & & & & & & 0.000 \\
\hline Yes & & & & & 62 & 5 & 34.25 (12.89-90.99) & \\
\hline No & & & & & 4 & 116 & & \\
\hline Female & 54 & 104 & & & 83 & 75 & & \\
\hline Male & 11 & 54 & $0.39(0.19-0.81)$ & & 20 & 45 & $0.40(0.22-0.74)$ & \\
\hline Rather not to say & 2 & 0 & 1 & & 1 & 1 & $0.9 .(0.06-14.7)$ & \\
\hline Home type & & & & 0.712 & & & & 0.449 \\
\hline Lives with another person & 45 & 19 & $1.69(0.43-6.67)$ & & 30 & 34 & $0.77(0.25-2.38)$ & \\
\hline $\begin{array}{l}\text { Living with more than two } \\
\text { people }\end{array}$ & 96 & 43 & $1.79(0.48-6.68)$ & & 64 & 75 & $0.75(0.26-2.17)$ & \\
\hline Exercise & & & & $0.033^{*}$ & & & & 0.213 \\
\hline More than once a day & 5 & 10 & & & 5 & 10 & & \\
\hline At least once a day & 16 & 55 & $0.58(0.17-1.95)$ & & 31 & 40 & $1.55(0.48-5.0)$ & \\
\hline $\begin{array}{l}\text { More than three times per } \\
\text { week }\end{array}$ & 5 & 25 & $0.4(0.09-1.69)$ & & 8 & 22 & $0.73(0.19-2.79)$ & \\
\hline Others & 2 & 0 & 1 & & 1 & 1 & $2(0.10-1.46)$ & \\
\hline Job type & & & & $0.006^{\star \star}$ & & & & 0.448 \\
\hline Unemployed & 4 & 9 & & & 6 & 7 & & \\
\hline Domestic work & 17 & 10 & $3.83(0.93-15.71)$ & & 17 & 10 & $1.98(0.52-7.58)$ & \\
\hline Student & 3 & 20 & $0.33(0.06-1.83)$ & & 7 & 16 & $0.51(0.13-2.08)$ & \\
\hline $\begin{array}{l}\text { Public job/studies } \\
\text { candidate }\end{array}$ & 0 & 4 & 1 & & 1 & 3 & $0.39(0.03-4.79)$ & \\
\hline Health professional & 6 & 9 & $1.5(0.31-7.19)$ & & 8 & 7 & $1.33(0.03-5.91)$ & \\
\hline Minimum service worker & 3 & 5 & $1.35(0.21-8.62)$ & & 4 & 4 & $1.17(0.20-6.80)$ & \\
\hline Food sector & 1 & 4 & $0.56(0.04-6.77)$ & & 1 & 4 & $0.29(0.03-3.37)$ & \\
\hline State security forces & 0 & 3 & 1 & & 1 & 2 & $0.58(0.04-8.15)$ & \\
\hline
\end{tabular}

Table 3 (continued) 
Table 3 (continued)

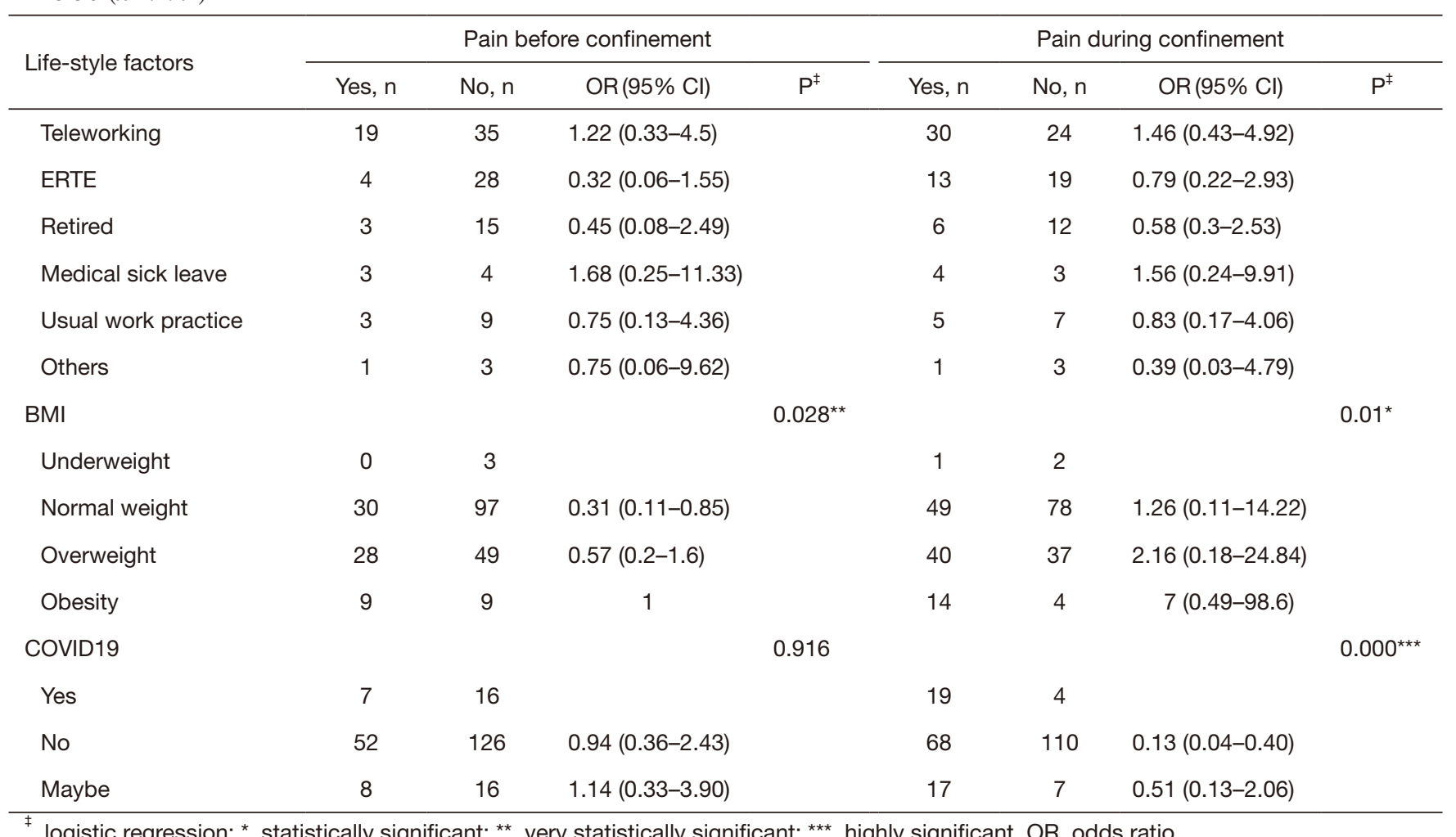

${ }^{\ddagger}$, logistic regression; ${ }^{*}$, statistically significant; ${ }^{* \star}$, very statistically significant; ${ }^{* \star \star}$, highly significant. OR, odds ratio.

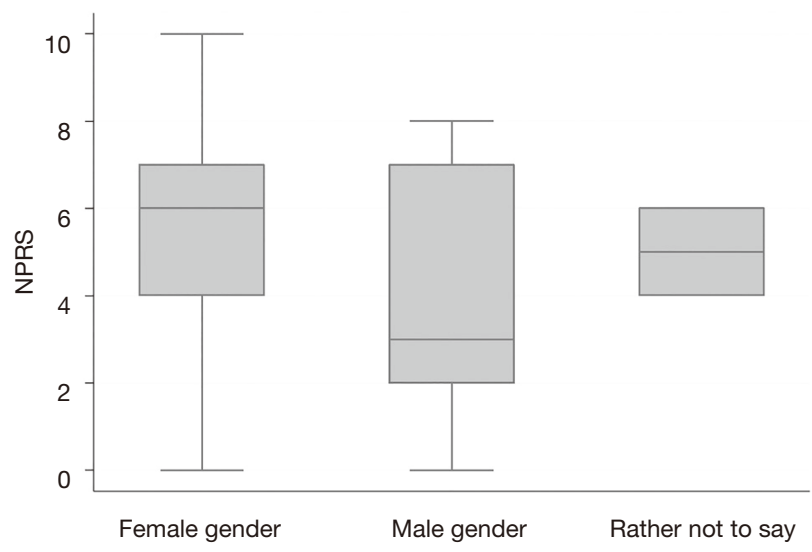

Figure 1 Relationship between pain and gender. Women not only suffer a higher mean of pain than men, but also suffer a wider pain range, reaching maximum levels on the Numeric Pain Rating Scale.

a wider range of pain, reaching maximum levels on this scale. Essential workers experiment a higher mean of pain that health professionals and domestic workers, but in a narrower range that domestic workers. People with other kind of jobs were the ones that suffered the most intense pain (Figure 2). Relating pain intensity with COVID-19 diagnosis, it draws for attention that, although there is a higher chance of suffering pain with a positive diagnosis of COVID-19, the wider range of pain suffered belongs to the negative diagnosis group, as both positive and negative diagnosis groups suffer a similar mean of pain intensity (Figure 3).

The items and scales of the SF-36v2 are rated so that the higher score represents the better the health status. For example, function scales are evaluated so that a high score indicates a better function; and in the pain scale, a high score indicates being pain free. When analysing the results on quality of life, it can be observed that the score of the degree to which health limits physical activity (FP) during confinement was $84.30 \%$ on average. The degree to which physical health interferes with work and other daily activities (PR) was $57.60 \%$, and the intensity of pain and its effect on habitual work (BP) was $66.90 \%$ on average within the total of the sample. Regarding the personal assessment of health that includes current health, 


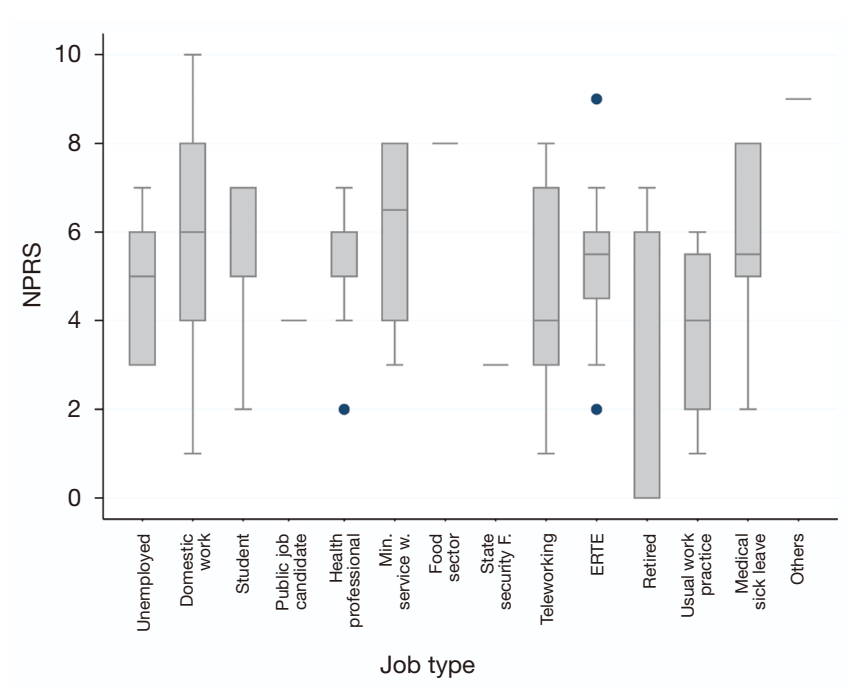

Figure 2 Relationship between pain and job type. Domestic workers suffer a mean of 6 at NPRS, being capable of suffering maximum levels on this scale. Essential workers experiment a higher mean of pain that health professionals and domestic workers. People with other kind of jobs were the ones that suffered the most intense pain. The population with a lower mean of pain is state security forces, with a mean of 3 at NPRS.

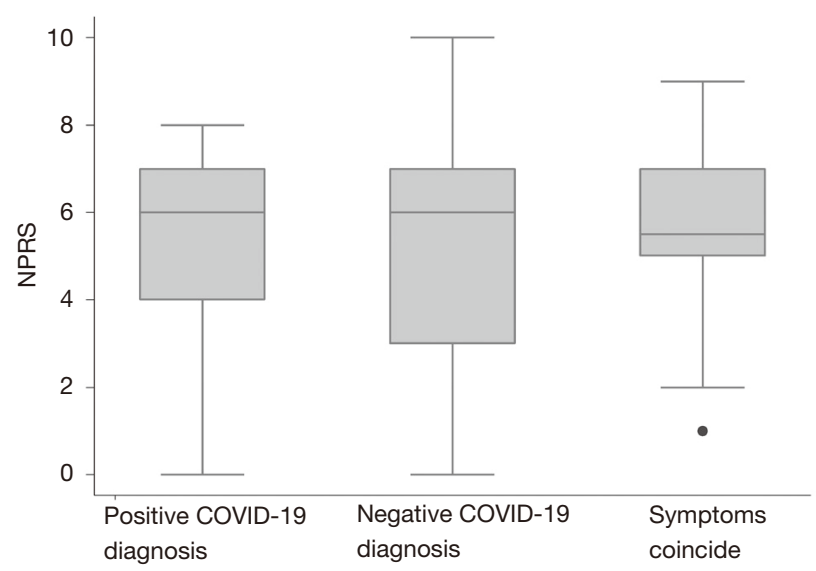

Figure 3 Relationship between pain and COVID-19 diagnosis. Although pain is one of the symptoms of COVID-19, people with a negative diagnosis of this disease suffers a similar mean of intensity of pain than people with positive diagnosis and are capable of suffering higher intensity of pain during confinement.

future health prospects and resistance to illness (GH), the average score obtained was $63.20 \%$, and the average score obtained on self-reported energy and vitality feeling, compared to the feeling of fatigue and exhaustion (VT) was $53.40 \%$. The score for the degree to which physical or emotional health problems interfered with their usual social life (SF) was $65.50 \%$, and the degree to which emotional problems interfered with work or other daily activities (RE) was scored with an average of $56.30 \%$. Finally, the general mental health $(\mathrm{MH})$ grade was scored with $60.50 \%$ (Figure 4). In general, the majority of the subjects (68.44\%) declared that their assessment of current health compared to that of a year ago was "more or less the same as a year ago", followed by "something worse than a year ago" by $19.11 \%$ of the respondents (Figure 5, Table 4). The declared health evolution did not show a statistically significant association with sex, companionship at home, exercising or having suffered from COVID-19 (or any of its symptoms) $(\mathrm{P}>0.05)$, but it did reflect a significant association with having suffered pain pre-confinement $(\mathrm{P}=0.001)$ and with having suffered pain during confinement $(\mathrm{P}=0.000)$, where individuals with pain felt worse than a year ago for both cases, with the type of employment $(\mathrm{P}=0.016)$, where workers who remote-worked from home or were furloughed (the British equivalent to the Spanish 'ERTE'Temporary Employment Regulation File). In this case, their situation and their BMI $(\mathrm{P}=0.025)$ worsened compared to the previous year, where both individuals with normal weight and those with obesity felt worse than a year ago (Table 5).

\section{Discussion}

Pain is defined as an unpleasant sensory and emotional experience associated with, or similar to that associated with actual or potential tissue, according to the International Association of the Study of Pain (IASP). Several types of pain are determined: neuropathic, nociceptive and nociplastic. In all definitions of pain, reference is made to the unpleasantness of the sensation, which includes emotional, affective, and even moral components, which are very important (16).

In the case of nociceptive or neuropathic pain the nervous system acts as a transducer of the natural stimuli that have activated the nociceptors; but pain, as a normal sensory experience, reflects the activation of sensory brain centers, including the somatosensory cortex and the prefrontal and limbic-affective areas. Pain is always a personal experience that is influenced to varying degrees by biological, psychological, and social factors. That is why pain and nociception are different phenomena. Pain cannot 


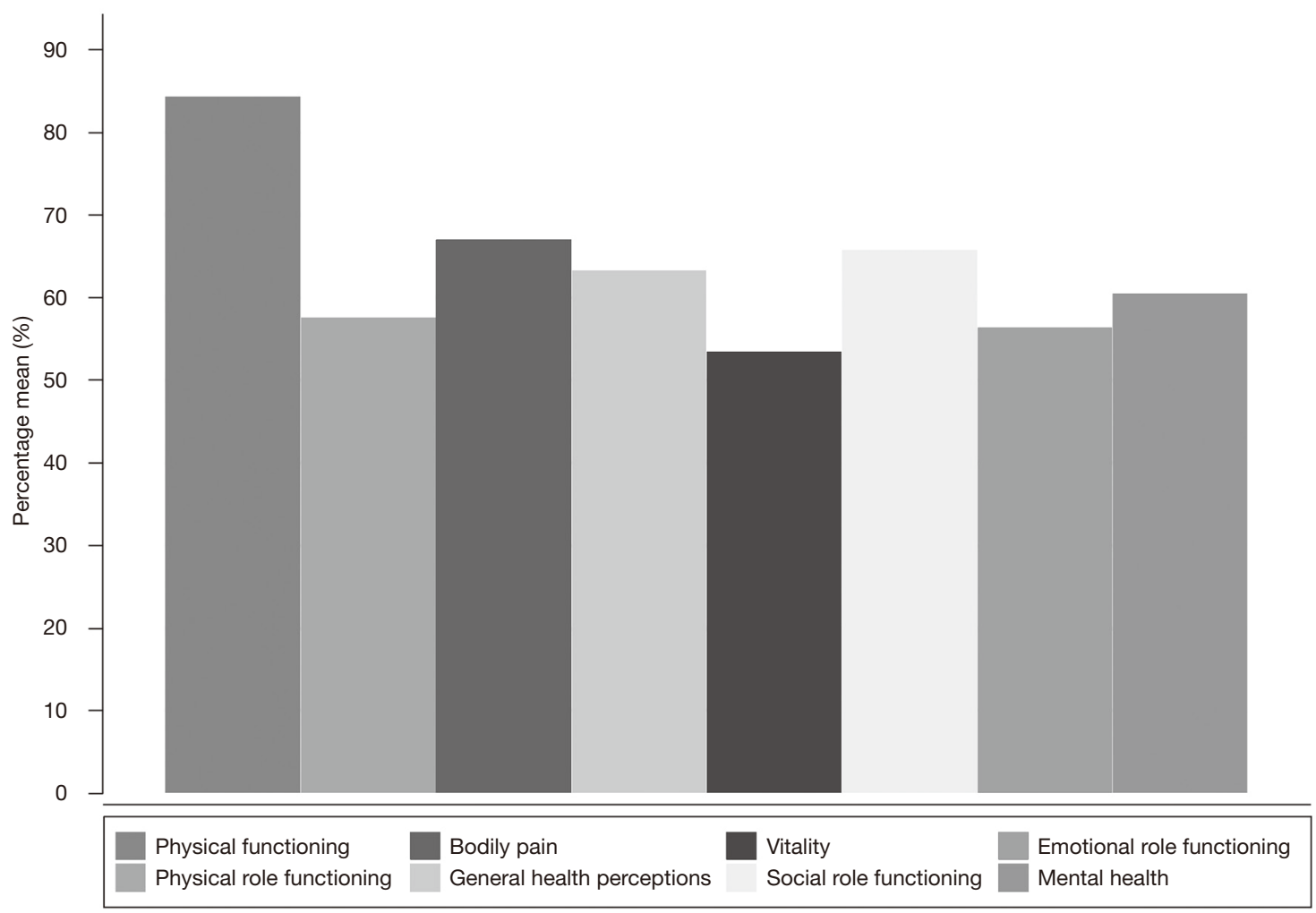

SF-36v2 items and scales

Figure 4 Relationship between confinement and quality of life (SF-36v2). Vitality is the most affected item during confinement, and Physical Functioning is the less affected item during confinement for our population.

be inferred solely from activity in sensory neurons because, as it has been reported, it refers to an experience that does not have to be mediated by these purely somatosensory mechanisms, and although pain usually has an adaptive role, it may have adverse effects on function and social and psychological well-being $(16,17)$.

Pain is the symptom most related to the disease and to the very essence of living, likewise, it is the greatest indicator of suffering (17). This arises in dramatic or unpleasant situations but also in those that are filled with joy. Furthermore, it is estimated that one in five Europeans suffers from chronic pain (19\%), and although there are no epidemiological studies carried out at national level, recent data argue that the estimated prevalence in Spain is slightly below than the European average (17\%) (18).

The complexity in measuring pain is an uncomfortable truth that is already advocated by the scientific field. The Pain Proposal initiative, published in 2014, already wanted to address this issue. Pain and its manifestations are subjective in nature and this makes it difficult to diagnose and identify the type of pain and thus its therapeutic possibilities. The data published in this study reflects a worrying situation, since a third of those surveyed took more than a year to be diagnosed and $13 \%$ remained without a diagnosis (18). Another current study refers to the importance of defining pain and doing it in such a way that it has unanimous acceptance can be a complex task, since it is an individual and subjective experience, to which is added the fact that there is no scientific method that makes it "measurable", and the perception of a heterogeneous group of nuances and sensations can increase its complexity (19).

That is why the anamnesis is extremely important in the assessment of the patient with pain, because it allows approximating the etiology of pain and identifying patients prone to suffering from it. That is why the use of scales for medical or research purposes must take into account the potential for error within the tools, and the potential they have to provide the required information (17). In the 


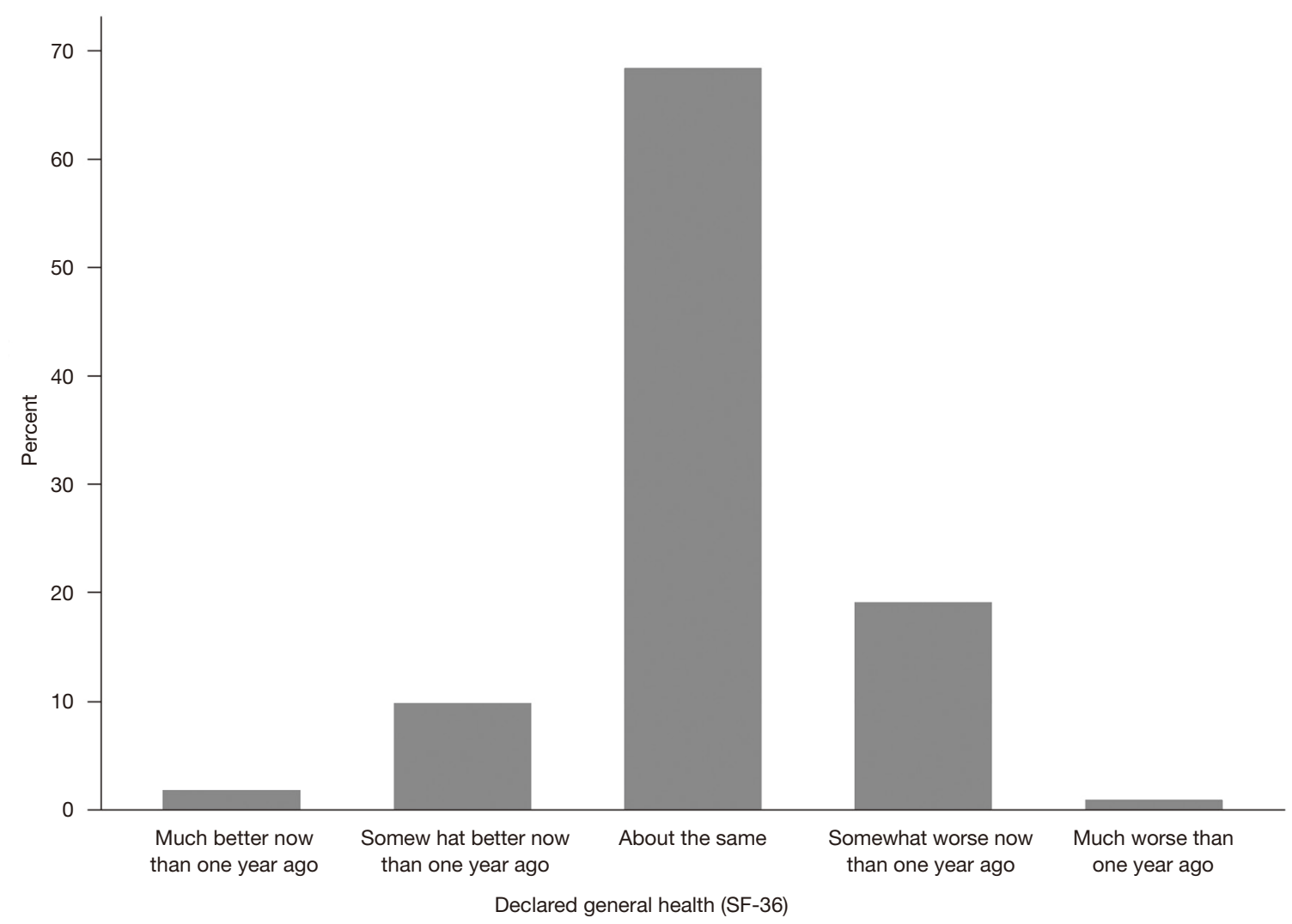

Figure 5 Relationship between confinement and Declared General Health. The majority of the sample declared that their perceived health were about the same than a year ago, following by the part of the sample that declared that their health was somewhat worse at that moment than a year ago.

assessment of pain within the concept of disability, it must be considered that disability is a multifactorial phenomenon and that non-clinical factors, including age, education, and employment status, are correlated with disability. For this reason, the question arises as to whether factors related to employment predict chronic pain and/or disability in those cases of chronic pain, and especially in pathologies so closely linked to the work environment where aspects such as the lack of work adaptation or autonomy can increase chronic pain disability. However, previous research still does not provide clear evidence that lack of job satisfaction, perceived conditions, difficult job demands, strong physical demands of work, private rather than public employment, and socio-economic group membership lower predict chronic pain. The weight of seniority in this concept is not conclusive. However, some studies provide moderate evidence that having a longer duration of pain predicts relapse (18).

Speaking in terms of a global pandemic, and what the semantics itself suggests, we are facing an unpleasant situation for the entire population, added to the physical limitations (home confinement, cessation of non-essential work activity, work demands on health and security forces of the State, limitation of social relations) imposed by the Government of Spain as measures to curb the impact of COVID-19 and the disease itself, with the symptoms that we already know, highlighting the generalized headache and musculoskeletal pain, and the associated fatigue. Likewise, it is necessary to highlight the uncertainty of death and the serious consequences of the disease that does not distinguish age or risk factors and that positively influences the painful experience $(1,3)$.

The aim of this study was to address, from a general point of view, the experience of pain during the time of 
Table 4 Quality of life during confinement

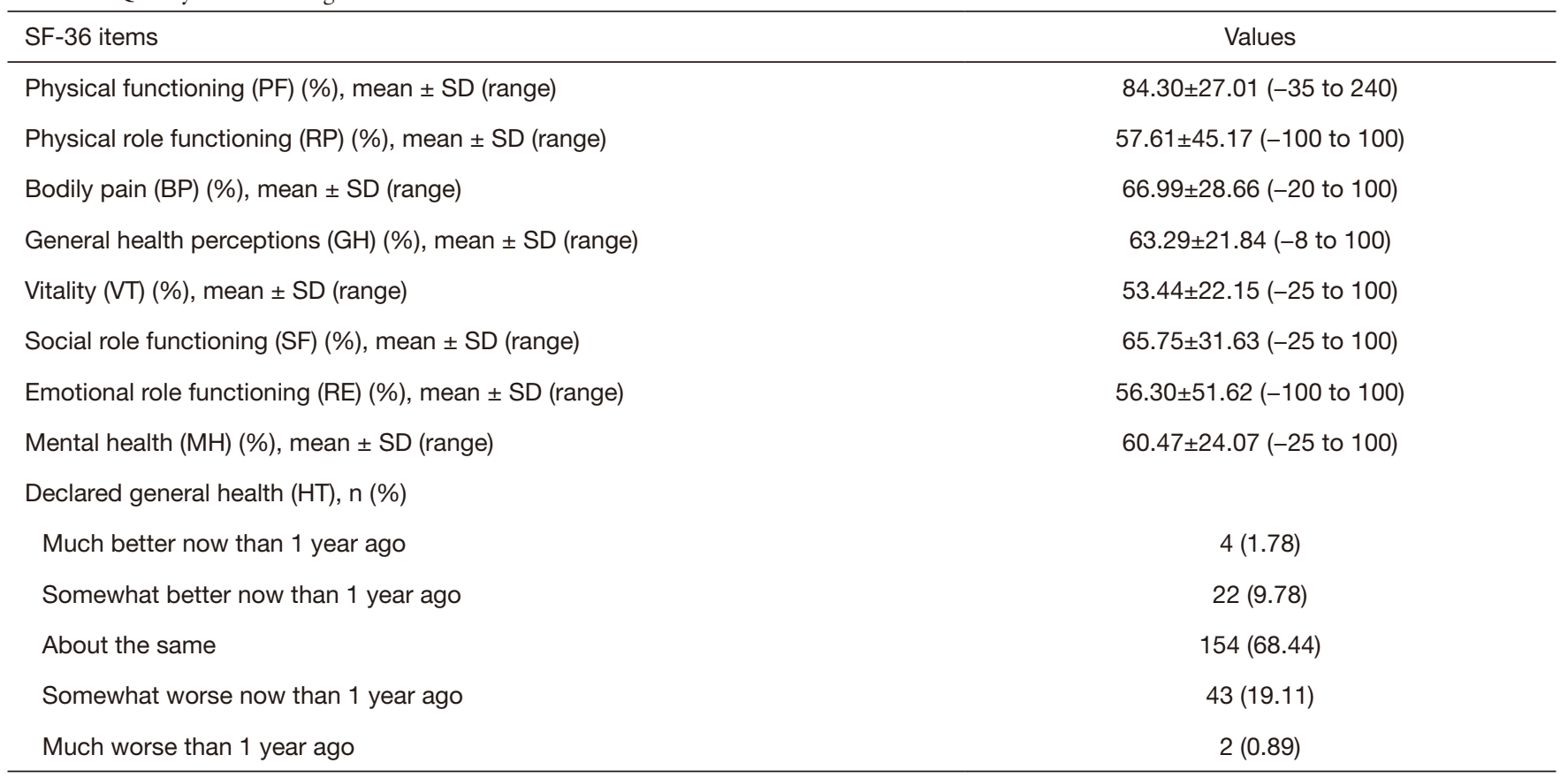

home confinement in Spain, seeking to relate its presence, without discerning the type or in which dimension it is most present (sensory, emotional or cognitive), with other possible triggers of the same in said period of time, such as loneliness, the job altered by the pandemic, the practice of physical exercise without being able to leave home, suffering from COVID-19; and other constant factors such as gender, BMI, and suffering pain prior to the confinement situation, always bearing in mind that we are talking about an approach in an unprecedented situation, without prior experience on this issue in Spain and trying to obtain a response to a concise questionnaire on pain and quality of life.

In China alone, a billion people have faced different restrictions due to various degrees of confinement. One month after the outbreak, in Spain as well as all over the world, most subjects of working age, were still unable to work and carry out their usual exercise routine. This can lead to potential health and wellbeing issues. The measures taken in China appeared to be effective in containing the spread of the virus in February 2020 and were supported by the WHO. Nevertheless, these measures have significantly disrupted people's lives $(6,7)$. Chinese college students have already reported experiencing a higher rate of stress and anxiety than previously, and various studies draw attention to worsening health and increased distress, which despite not being statistically significant, convey preliminary evidence about the health conditions of adults in the regions affected by COVID-19.

Confinement in Spain has been universal across the entire country, with some specific measures for those who showed symptoms or had been diagnosed with the disease (4). At the time of writing, no serological tests have been performed on the general population, making it impossible to estimate the actual prevalence of infection within the population (20). Thus, there is a proportion of symptomatic subjects who have not had the presence of the virus verified, i.e, the prevalence of the virus could be much higher than that estimated.

In the present study, a relationship has been found between suffering pain and the employment conditions in domestic workers, health personnel and essential workers. These results can be related to those of Shinyoung, who found that the subjective health of the workers was different if they were precarious workers or not (the health of unregulated employment being worse, such as housework and of the employees who worked the longest shifts, such as essential workers and health personnel), which in turn was related to gender, where women suffered the most pain (21). Additionally, several authors have identified a potential negative impact on the health of precarious workers and nursing workers $(13,22,23)$, and of these, specifically on 
Table 5 Relationship between pain, quality of life and life-style factors

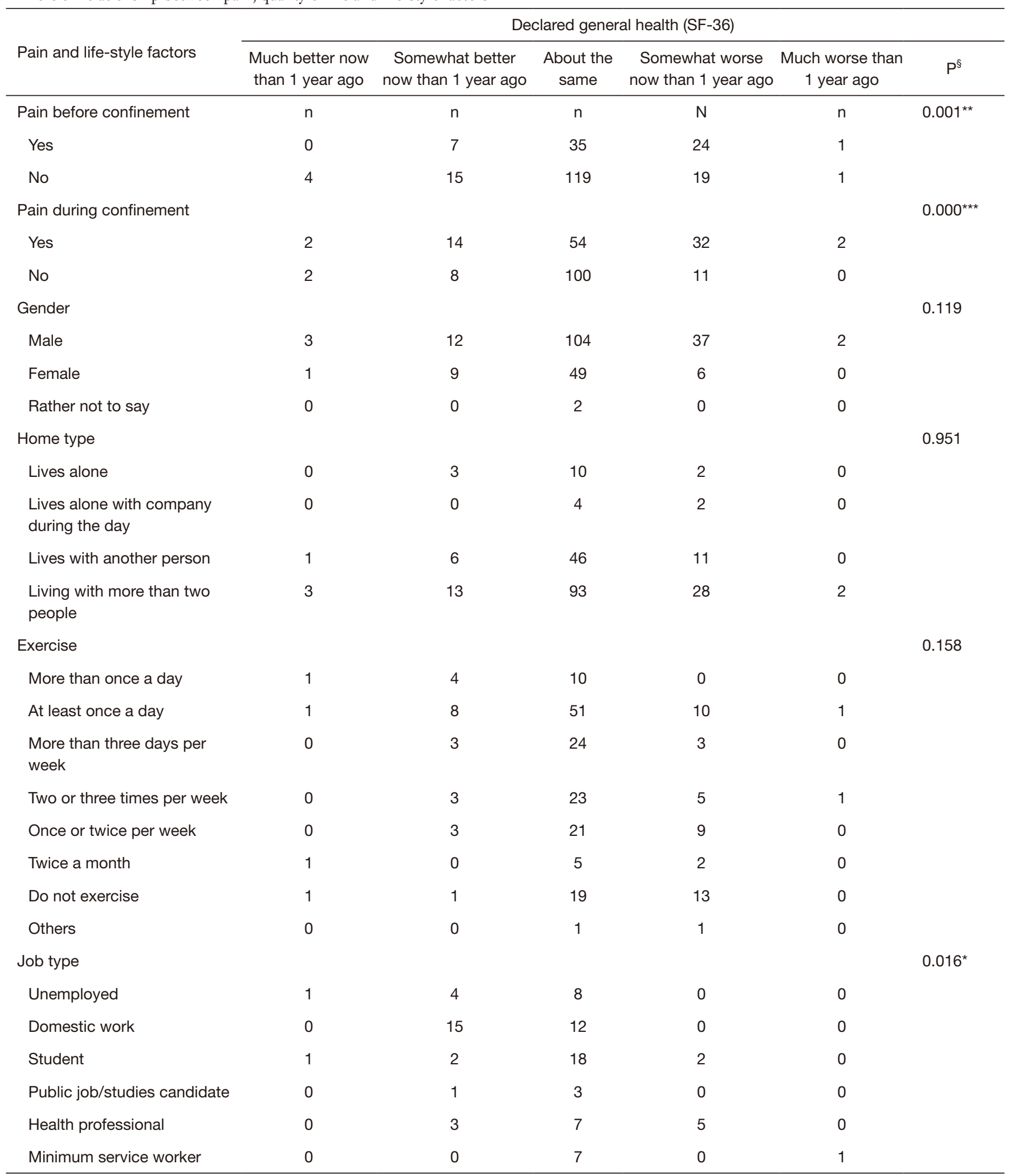

Table 5 (continued) 
Table 5 (continued)

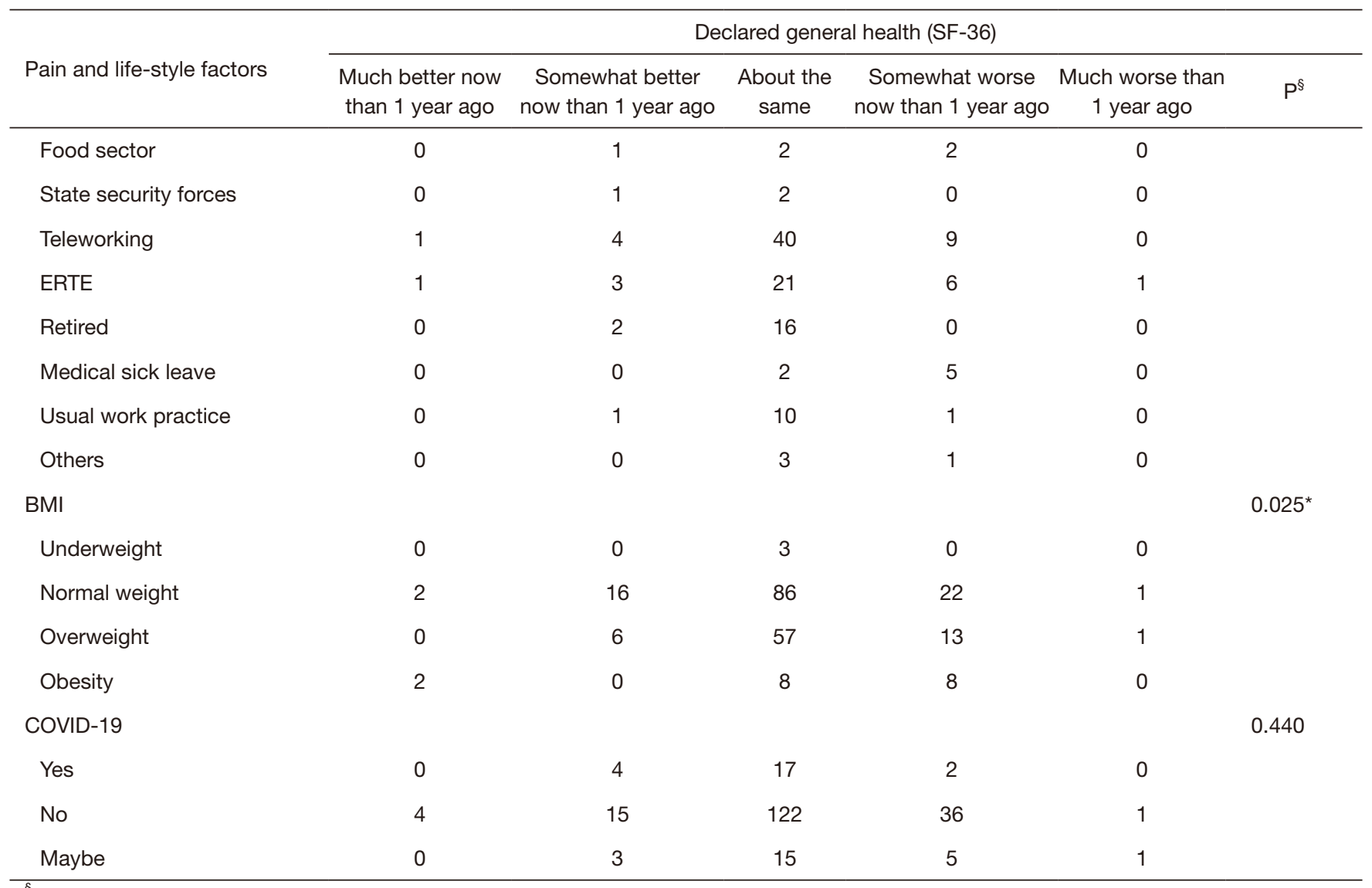

\$, Pearson's Ji squared; *, statistically significant; ${ }^{\star \star}$, very statistically significant; ${ }^{\star \star *}$, highly significant.

women $(10,24,25)$. Furthermore, the studied sample in this study has shown that suffering pain can be related to exercising (comparing doing no exercise to exercising daily). Carrying out physical activity has sometimes been associated with better levels of health, both physically and mentally, in various populations (21), showing a link between good physical activity and lower levels of pain. That is why, to explain the present results, it must be taken into account that it is very possible that the subjects who exercised daily and had pain did so precisely to control their symptoms. Similarly, a high BMI has been associated with suffering pain, which is consistent with the research undertaken by other authors (11). What is striking about these results is that, during confinement, the number of people who expressed pain essentially doubled, and indicators such as employment status and physical activity cease were very important, in addition to being female, having a high BMI, having existing pain and having the virus, in relation to pain suffering. As previously mentioned, the COVID-19 symptoms include muscle pain (1), which could explain the increase in pain within the sample, as this represented a similar percentage to those who already had the disease or thought they had it. The importance of other factors on pain, such as gender and BMI, has already been discussed, but it seems that its impact on pain continues when other important indicators cease to have it, unlike other factors, such as employment status. Other reports show that during the COVID-19 crisis, the Chinese health personnel have suffered extremely high pressure due to increased shifts, higher working hours and the challenge of dealing with an unknown disease affecting the population, which has impacted on people's health (26). The obtained results are unable to relate pain to work stress in this situation. The results of various studies suggest that there may be longterm consequences not only for those affected by the quarantine, but also for the health system that administers it, as well as, politicians and public health officials who have dealt with creating the virus measures. For example, 
three years after the SARS crisis (in 2003), alcohol abuse or other dependency symptoms have been linked to health professionals and the quarantine period or living with people undergoing it (27).

Regarding the relationship between confinement and quality of life, the results on physical function (FP) are striking, as quality of life is the variable that has been least affected. In this sense, and despite the fact that confinement limits this sphere, the subjects do not believe that their quality of life has been greatly affected. However, the physical role (RF), the emotional role (RE) and mental health $(M H)$, which are severely affected. In this sense, both the physical and the emotional state, which allow us to carry out daily, are revealed to be very affected by confinement. In other similar studies, it was found that confinement did not cause increased stress in families, work or financial environments, despite subjects declaring that they felt horrified and apprehensive individually, which made them pay more attention to their mental health $(6,7)$. At the time of writing, a study was carried out whose preliminary results indicate that the mental health of $46 \%$ of Spaniards was at risk due to the COVID-19 crisis, but to interpret these results, one must wait for its definitive outcome (2).

Furthermore, although the majority of subjects declared that their health was approximately the same as a year ago, some subjects considered their health worse than the previous year. Linking this variable to the others, there is a relation between having pain before and during confinement, employment and BMI, but the other variables did not show associations. It is worth noting that both infected and non-infected subjects with the disease have a psychological stress response to COVID-19, which could have long-term health consequences (26). Unfortunately, not many similar studies have been found with which to establish a proper discussion. Although in the Chinese population increased stress, anxiety, sleeping problems and fear during confinement has been pointed out in studies (mainly within health personnel and state security forces) (26). Our data shows a reduction in quality of life in teleworkers, who may have suffered problems related to family reconciliation and disconnection from work, and in furloughed workers, who may have felt fear or anxiety about their job uncertainty. Home schooling has not been found to be associated with this statement. In other studies, the Chinese subjects declared feeling more supported by their families and being more aware of feelings in relation to the relatives around them during confinement (28). In the United States of America, great care has been taken to combat loneliness and isolation in the elderly population during confinement (29). Given the high rate of infections by COVID-19, China, the United Kingdom and the United States have implemented psychological care services for those affected by the virus and their families, but they do not maintain this activity once they stop having the disease actively or if the affected family member passes away. This measure is not applicable to confined healthy people. It has been documented that patients, once recovered and discharged, continue showing stress and anxiety symptoms which cannot be ignored (30). Although physical activity seems to improve the quality of life in many scenarios $(23,28,31-33)$, this has not been reported as one of them. This is not the case with the relationship with the subject's BMI, which confirms once again that the higher the BMI, the greater impact on the quality of life $(12,23)$. Unfortunately, the obtained data is limited and there are few studies about the impact of confinement on healthy and sick populations. This highlighted the need for further studies in this field.

Daring investigations have already been published that point out that the reorganization of healthcare is crucial not only to help patients with COVID-19, but also those with emotional disorders due to the epidemic, such as due to the containment of the general population during the state of $\operatorname{alarm}(10,34)$.

The present study has various limitations, mostly due to the nature of the subject of study. The desired sample size had to be limited so as not to alter the responses due to the change in the nature of the confinement imposed. Likewise, it has been decided to not geographically limit the responses of the subjects since all the regions of Spain were subject to the same restrictions during the Declaration of the State of Alarm. In order to control confounding bias as much as possible, it was chosen to perform simple regression analyses to check one by one whether the variables were related or not. In this sense, all non-statistically significant results could lead to a confounding factor, although it seemed important to us to include even non-significant results since we have not found any bibliography that suggests eliminating them. On the other hand, and although the comparison of two proportions is a particular case of logistic regression, it is true that chi square results show association purely. Keeping that in mind, we can recommend to take those results with caution, as further analysis to test confounding bias can be done in order to assure this association is not spurious. It is necessary to keep in mind Hawthorne effect. We tried to 
minimize this by making the questionnaire as anonymous as possible, written in a way that could not produce bias. It is a very delicate subject when it comes to measuring an experience as multidimensional as pain, but in the end, we understand that it is not applicable in this case, as it has been proposed the use of this label should be restricted to evaluations in which conformity and social desirability considerations are involved (35). Furthermore, we did not obtain previous data from the same subjects or data from unconfined people that we could use as a comparative control group. The pain data do not indicate a predictor of the specific type of pain suffered or to what extent each area of pain is affected (cognitive, emotional or sensitive). The questionnaire is brief and data such as the place of residence within Spain, personal history record, previous suffering from a chronic disease that causes pain (for example, cancer) could have been collected as data that may interfere with the results and provide clarifying results. There are also no previous similar studies and the research was carried out at the beginning of the arrival of COVID-19 in Spain, at which time the incidence of it in the population was not yet known. It should be emphasized that the data have been collected and analyzed by the main investigators, in the absence of blinding.

Suffering pain supposes to be living an unpleasant personal and subjective experience that can be influenced to a greater or lesser extent in one or more spheres of which it is composed. Having said this, it cannot be ruled out the idea that pain is present in our daily lives, as a mean of alarm for the central nervous system in adverse situations. For this reason, it cannot be stated that confinement is the only factor that influences this experience. The respondents determined whether before confinement they suffered pain, and how confinement influenced it, as well as whether the pain began during confinement and was acute (of short duration) or acquired a chronic behavior, since some studies provide evidence that a longer duration of pain predicts subsequent recurrence (17). All Spain was forced into compulsory home confinement and, as health professionals; we were interested in knowing what impact this situation would have on the population physical capacity. How this situation could be related to suffering pain, since physical exercise has a very important role in the aspects related to pain $(12,13)$, was also investigated. To our surprise, we did not find as many limitations on physical plane as in the psychological plane, which is considerably affected. This raises new lines of research on the idea of knowing more about the influence of the measures adopted by the government on the mental health of Spaniards and its direct influence with the so-called "pandemic" fatigue and chronic pain as a sequel to COVID-19. There is a need for further studies on this area.

\section{Conclusions}

The pandemic generated by the presence of COVID-19 has been associated with two health states that must be managed with priority: those due to infection per se and those derived from confinement, both in apparent healthy and infected people. The presence of pain in subjects undergoing confinement is persistent, with varying intensity and frequency based on age, gender, physical activity, and work status. In any of these conditions, the quality of life of the subjects in confinement has been severely affected, which to this day creates a severe public health problem.

\section{Acknowledgments}

The authors want to thank all volunteers that participated on this study.

Funding: None.

\section{Footnote}

Provenance and Peer Review: This article was commissioned by the editorial office, Annals of Palliative Medicine for the series "International Conference on Palliative Care and Medicine". The article has undergone external peer review.

Reporting Checklist: The authors have completed the STROBE reporting checklist. Available at http://dx.doi. org/10.21037/apm-20-2514

Data Sharing Statement: Available at http://dx.doi. org/10.21037/apm-20-2514

Conflicts of Interest: All authors have completed the ICMJE uniform disclosure form (available at http://dx.doi. org/10.21037/apm-20-2514). The series "International Conference on Palliative Care and Medicine" was commissioned by the editorial office without any funding or sponsorship. The authors have no other conflicts of interest to declare.

Ethical Statement: The authors are accountable for all aspects of the work in ensuring that questions related 
to the accuracy or integrity of any part of the work are appropriately investigated and resolved. The study was conducted in accordance with the Declaration of Helsinki (as revised in 2013). The study was submitted to the Committee for Research Ethics with drugs of the Health Area of Burgos and Soria, and due to the characteristics of the study, a waiver was provided. And all participants fill in the questionnaire knowing that their data will be used for scientific purposes.

Open Access Statement: This is an Open Access article distributed in accordance with the Creative Commons Attribution-NonCommercial-NoDerivs 4.0 International License (CC BY-NC-ND 4.0), which permits the noncommercial replication and distribution of the article with the strict proviso that no changes or edits are made and the original work is properly cited (including links to both the formal publication through the relevant DOI and the license). See: https://creativecommons.org/licenses/by-nc-nd/4.0/.

\section{References}

1. Lai CC, Shih TP, Ko WC, et al. Severe acute respiratory syndrome coronavirus 2 (SARS-CoV-2) and coronavirus disease-2019 (COVID-19): The epidemic and the challenges. Int J Antimicrob Agents 2020;55:105924.

2. García M. Coronavirus y estudio de prevalencia: inicio con "heterogeneidad absoluta". Redacción Médica, Publicación Médica de Medicina de Familia (electronic magazine). Accessed April 20th, 2020. Available online: https://www. redaccionmedica.com/secciones/medicina-familiar-ycomunitaria/coronavirus-y-estudio-de-prevalencia-iniciocon-heterogeneidad-absoluta--6796

3. España. Real Decreto-ley 463/2020, de 14 de marzo, por el que declara el estado de alarma para la gestión de la situación de crisis sanitaria ocasionada por el COVID-19. Boletín Oficial del Estado, 14 de marzo de 2020, núm. 67, pp 25390 a 25400. Accessed April 30th, 2020. Available online: https://www.boe.es/diario_boe/txt. php?id=BOE-A-2020-3692

4. España. Orden SND/387/2020, de 3 de mayo, por la que se regula el proceso de cogobernanza con las comunidades autónomas y ciudades de Ceuta y Melilla para la transición a una nueva normalidad. Boletín Oficial del Estado, 3 de mayo de 2020, núm 123, pp. 31113 a 31117. Accessed May 3rd, 2020. Available online: https://www.boe.es/eli/es/ o/2020/05/03/snd387

5. España. Real Decreto-ley 8/2020, de 17 de marzo, de medidas urgentes extraordinarias para hacer frente al impacto económico y social del COVID-19. Boletín Oficial del Estado, 7 de marzo de 2020, núm. 73, pp 25853 a 25898. Accessed May 3rd, 2020. Available online: https:// www.boe.es/eli/es/rdl/2020/03/17/8

6. Zhang Y, Ma ZF. Impact of the COVID-19 pandemic on mental health and quality of life among local residents in Liaoning Province, China: A cross-sectional study. Int J Environ Res Public Health 2020;17:2381.

7. Zhang SX, Wang Y, Rauch A, et al. Unprecedented disruption of lives and work: Health, distress and life satisfaction of working adults in China one month into the COVID-19 outbreak. Psychiatry Res 2020;288:112958.

8. Chen P, Mao L, Nassis GP, et al. Coronavirus disease (COVID-19): The need to maintain regular physical activity while taking precautions. J Sport Health Sci 2020;9:103-4.

9. Ponka D, Agbata E, Kendall C, et al. The effectiveness of case management interventions for the homeless, vulnerably housed and persons with lived experience: A systematic review. PLoS One 2020;15:e0230896.

10. Roberts AR, Ishler KJ. Family Involvement in the Nursing Home and Perceived Resident Quality of Life 10. Gerontologist 2018;58:1033-43.

11. Bartley M. Measuring women's social position: The importance of theory. J Epidemiol Community Health 1999;53:601-2.

12. Balkić J, Radoš I, Banjari I. Changes in dietary habits of patients with chronic pain represent contributing factors to decreased pain intensity and improved quality of life. Pilot study from Croatia. Nutr Hosp 2020;34:577-83.

13. Laxy M, Teuner C, Holle R, et al. The association between BMI and health-related quality of life in the US population: Sex, age and ethnicity matters. Int J Obes (Lond) 2018;42:318-26.

14. Benach J, Vives A, Amable M, et al. Precarious Employment: Understanding an Emerging Social Determinant of Health. Annu Rev Public Health 2014;35:229-53.

15. Gander P, O'Keeffe K, Santos-Fernandez E, et al. Development and evaluation of a matrix for assessing fatigue-related risk, derived from a national survey of nurses' work patterns. Int J Nurs Stud 2020;112:103573.

16. Raja SN, Carr DB, Cohen M, et al. The revised International Association for the Study of Pain definition of pain: concepts, challenges, and compromises. Pain 2020;161:1976-82.

17. Vicente-Herrero MT, Delgado-Bueno S, Bandrés-Moyá F, 
et al. Valoración del dolor. Revisión comparativa de escalas y cuestionarios. Rev Soc Esp Dolor 2018;25:228-36.

18. Catafau S. Tratado de dolor neuropático. 1st ed. Spain: Editorial Médica Panamericana, 2007.

19. Torralba A, Miquel A, Darba J. Situación actual del dolor crónico en España: iniciativa "Pain Proposal". Rev Soc Esp Dolor 2014;21:16-22.

20. Gobierno de España, Ministerio de Ciencia e Innovación, Ministerio de Sanidad, Consejo Interterritorial Sistema Nacional de Salud, Instituto de Salud Carlos III. Estudio ENE-COVID19: Primer Ronda. Estudio nacional de seroepidemiología de la infección por SARS-CoV-2 en España. Informe preliminar 13 de mayo, 2020. Available online: https://www.20minutos.es/noticia/4257189/0/informeseroprevalencia-coronavirus-espana/

21. Shinyoung S. The Effect of Regular Workers and Nonregular Workers on the Subjective Health Status. Korean J Occup Health Nurs 2011;20:346-55.

22. Burgess J, Campbell I. The Nature and Dimensions of Precarious Employment in Australia. Labour Industry 1998;8:5-21.

23. Baile JI, Guevara RM, González-Calderón MJ, et al. The Relationship Between Weight Status, Health-Related Quality of Life, and Life Satisfaction in a Sample of Spanish Adolescents. Int J Environ Res Public Health 2020;17:E3106.

24. Menéndez M, Benach J, Muntaner C, et al. Is precarious employment more damaging to women's health than men's? Soc Sci Med 2007;64:776-81.

25. Park SJ, Kim SY, Lee ES, et al. Associations Among Employment Status, Health Behaviors, and Mental Health in a Representative Sample of South Koreans. Int J Environ Res Public Health 2020;17:2456.

26. Yuan S, Liao Z, Huang H, et al. Comparison of the Indicators of Psychological Stress in the Population of Hubei Province and Non-Endemic Provinces in China During Two Weeks During the Coronavirus Disease 2019
(COVID-19) Outbreak in February 2020. Med Sci Monit 2020;26:e923767.

27. Brooks SK, Webster RK, Smith LE, et al. The Psychological Impact of Quarantine and How to Reduce It: Rapid Review of the Evidence. Lancet 2020;395:912-20.

28. Gallego-Méndez J, Perez-Gomez J, Calzada-Rodríguez JI, et al. Relationship between Health-Related Quality of Life and Physical Activity in Children with Hyperactivity. Int J Environ Res Public Health 2020;17:E2804.

29. Berg-Weger M, Morley JE. Editorial: Loneliness and Social Isolation in Older Adults During the COVID-19 Pandemic: Implications for Gerontological Social Work. J Nutr Health Aging 2020;24:456-8.

30. Duan L, Zhu G. Psychological interventions for people affected by the COVID-19 epidemic. Lancet Psychiatry 2020;7:300-2.

31. Vagetti GC, Barbosa Filho VC, Moreira NB, et al. Association Between Physical Activity and Quality of Life in the Elderly: A Systematic Review, 2000-2012. Braz J Psychiatry 2014;36:76-88.

32. Choi MJ, Park YG, Kim YH, et al. Association Between Type of Exercise and Health-Related Quality of Life in Adults Without Activity Limitations: A Nationwide CrossSectional Study. BMC Public Health 2020;20:599.

33. Wu XY, Han LH, Zhang JH, et al. The Influence of Physical Activity, Sedentary Behavior on Health-Related Quality of Life Among the General Population of Children and Adolescents: A Systematic Review. PLoS One 2017;12:e0187668.

34. Chevance A, Gourion D, Hoertel N, et al. Ensuring mental health care during the SARS-CoV-2 epidemic in France: A narrative review. Encephale 2020;46:S3-13.

35. McCambridge J, Witton J, Elbourne DR. Systematic review of the Hawthorne effect: new concepts are needed to study research participation effects. J Clin Epidemiol 2014;67:267-77.
Cite this article as: Iglesias-López E, García-Isidoro S, Castellanos-Sánchez VO. COVID-19 pandemic: pain, quality of life and impact on public health in the confinement in Spain. Ann Palliat Med 2021;10(4):4338-4353. doi: 10.21037/apm-20-2514 


\section{Supplementary}

\section{Pain and health questionnaire: COVID-19}

After everything we have experienced during this last month due to the COVID-19 pandemic, we are all noticing different changes in our health. We may have experienced changes, both positive and negative, when it comes to pain and health.

In order to learn a little more about the impact of COVID-19 on the population, this pain and quality of life questionnaire has been created. The initial questionnaire will take you about 5 minutes at most to answer, but the second part will take you a little longer $(15 \mathrm{~min})$. At the beginning, a series of demographic data is requested and the rest of the questions (Health Questionnaire SF-36) will have to be answered by selecting one of the options indicated. This questionnaire will be used for scientific purposes. Thanks for your help and collaboration.

\begin{tabular}{|l|l|l|l|l|}
\hline Age (years) & \multicolumn{3}{|l|}{} \\
\hline Weight $(\mathrm{kg})$ & \multicolumn{4}{|l|}{} \\
\hline Height $(\mathrm{cm})$ & \multicolumn{3}{|l|}{} \\
\hline Gender & Female & Male & I prefer not to say & Other \\
\hline
\end{tabular}

- Whit many people are you living during lockdown?

$\square$ Lives alone

$\square$ Lives alone with company during the day

$\square$ Lives with another person

$\square$ Living with more than two people

- What is your job during the state of alarm?

$\square$ Unemployed

$\square$ Domestic work

$\square$ Student

$\square$ Public job/studies candidate

$\square$ Health professional

$\square$ Minimum service worker

$\square$ Food sector

$\square$ State security forces

$\square$ Teleworking

$\square$ Furloughed (the British equivalent to the Spanish 'ERTE')

$\square$ Retired

- Medical sick leave

$\square$ Usual work practice

$\square$ Other

- Are you practicing physical exercise during confinement?

$\square$ More than once a day

$\square$ At least once a day

$\square$ More than three times per week

$\square$ Two or three times per week

$\square$ One or two times per week

$\square$ Twice a month

$\square$ I do not practice exercise 
$\square$ Other

- Have you had symptoms of COVID-19 or have you been diagnosed with it throughout this 2020?

$\square$ Yes

$\square$ No

$\square$ Maybe (symptoms coincide), but I have not been diagnosed

- Have you suffered pain before the period of confinement?

$\square$ Yes

$\square \mathrm{No}$

- Have you suffered pain throughout the period of confinement?

$\square$ Yes

$\square \mathrm{No}$

- If so, indicate one of the options:

$\square$ The pain has increased

$\square$ The pain has remained

$\square$ Previous pain has disappeared

$\square$ The pain suffered during confinement has been brief (max. 7 days) and has disappeared

- If you answered yes to previous question, what is the intensity of this current pain? Please, answer on this scale, keeping in mind that 0 is no pain and 10 the worst possible pain.

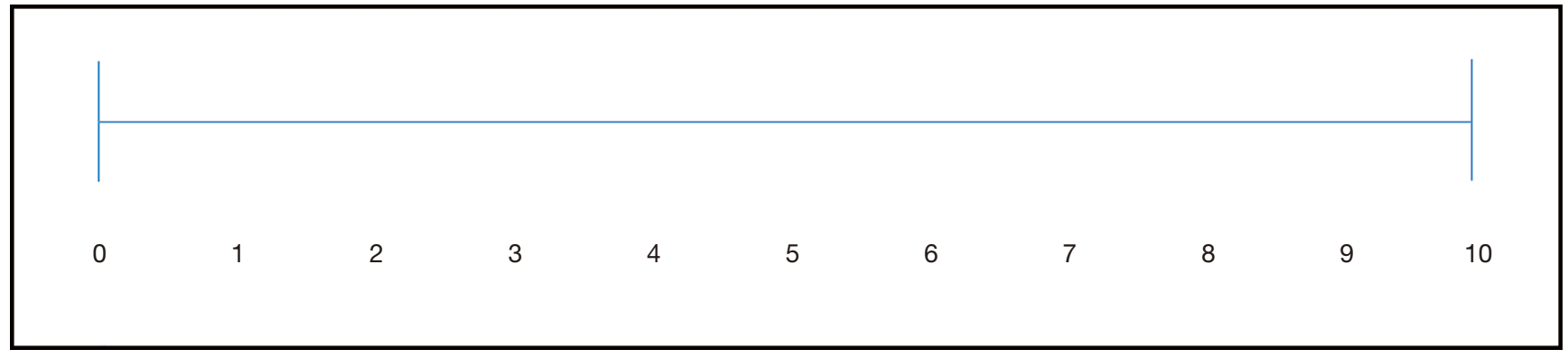

\section{Health questionnaire in the state of alarm for COVID-19}

In this section we ask you for answers about your health status during the last four weeks. Thank you very much for your help.

(I) In general, you would say that your current health is...?
a) Excellent
b) Very good
c) Good
d) Regular
e) $\mathrm{Bad}$

(II) How would you say is your current health compared to a year ago?
a) Much better now than a year ago
b) Something better now than a year ago
c) More or less the same as a year ago
d) Something worse now than a year ago
e) Much worse now than a year ago

(III) The next questions ask about activities or things that you could do on a typical day. Does your current health limit you to do those activities or things? If so, how much? 


\begin{tabular}{|c|c|c|c|}
\hline & $\begin{array}{l}\text { Yes, it limits me } \\
\text { a lot }\end{array}$ & $\begin{array}{l}\text { Yes, it limits me } \\
\text { a little }\end{array}$ & $\begin{array}{l}\text { No, it doesn't } \\
\text { limit me at all }\end{array}$ \\
\hline \multicolumn{4}{|c|}{ Intense exertion: running, lifting heavy objects, participating in strenuous sports } \\
\hline \multicolumn{4}{|c|}{ Moderate effort: moving a table, vacuuming, walking more than an hour } \\
\hline \multicolumn{4}{|l|}{ Take or carry the shopping bag } \\
\hline \multicolumn{4}{|c|}{ Climb the ladder up a single floor } \\
\hline \multicolumn{4}{|l|}{ Crouch or kneel } \\
\hline \multicolumn{4}{|l|}{ Walk a kilometer or more } \\
\hline \multicolumn{4}{|l|}{ Walk several hundred meters } \\
\hline
\end{tabular}

(IV) During the past 4 weeks, how often have you had any of the following problems at work or in your daily activities due to your physical health?

\begin{tabular}{|c|c|c|c|c|c|}
\hline & Always & Almost always & Sometimes & Only once & Never \\
\hline $\begin{array}{l}\text { Did you have to stop doing some tasks at work or in your da } \\
\text { activities? }\end{array}$ & & & & & \\
\hline
\end{tabular}

(V) During the last 4 weeks, how often have you had any of the following problems at work or in your daily activities, caused by an emotional problem (such as being sad, depressed, or nervous)?

\begin{tabular}{|c|c|c|c|c|c|}
\hline & Always & Almost always & Sometimes & Only once & Never \\
\hline $\begin{array}{l}\text { Did you do your work or daily activities less carefully than } \\
\text { usual due to an emotional problem? }\end{array}$ & & & & & \\
\hline
\end{tabular}

(VI) During the past 4 weeks, to what extent has your physical health or emotional problems hindered your usual social activities with family, friends, neighbors, or others?
a) Nothing
b) A little
c) Regular
d) Quite
e) A lot

(VII) Did you have pain in any part of your body in the last 4 weeks?
a) No, none
b) Yes, very little
c) Yes, a little 
d) Yes, moderate

e) Yes, a lot

f) Yes, very much

(VIII) During the past 4 weeks, to what extent has pain made it difficult for you to do your usual work (including working outside the home and housework)?
a) Nothing
b) A little
c) Regular
d) Quite
e) A lot

(IX) The questions that follow are about how you have been feeling and how things have been for you over the past 4 weeks. For each question, answer what is most like how you have felt. During the past 4 weeks, how often did ...

\begin{tabular}{|c|c|c|c|c|c|}
\hline & Always & Almost always & Sometimes & Only once & Never \\
\hline \multicolumn{6}{|c|}{ Did you feel full of vitality? } \\
\hline \multicolumn{6}{|c|}{ Did you feel very nervous? } \\
\hline \multicolumn{6}{|c|}{ Did you feel so low in morale that nothing could cheer you up? } \\
\hline \multicolumn{6}{|c|}{ Did you feel calm and peaceful? } \\
\hline \multicolumn{6}{|c|}{ Did you feel too depressed? } \\
\hline \multicolumn{6}{|c|}{ Did you feel exhausted? } \\
\hline \multicolumn{6}{|l|}{ Did you feel happy? } \\
\hline Did you feel tired? & & & & & \\
\hline
\end{tabular}

(X) During the past 4 weeks, how often have physical health or emotional problems made it difficult for you to do social activities (such as visiting friends or family)?
a) Always
b) Almost always
c) Sometimes
d) Only once
e) Never

(XI) Please state whether you think each of the following statements is TRUE or FALSE:

\begin{tabular}{|c|c|c|c|c|c|}
\hline & Completely true & Pretty much true & I don't know & Pretty much false & Completely false \\
\hline \multicolumn{6}{|c|}{ I am as healthy as anyone } \\
\hline \multicolumn{6}{|c|}{ I think my health is going to get worse } \\
\hline
\end{tabular}

